\title{
AN IMPROVED METHOD FOR ISOLATION OF THIELAVIOPSIS PARADOXA FROM STEM BLEEDING AFFECTED COCONUT PALMS
}

\author{
Anil Kumar and K.K.N. Nambiar ${ }^{1}$
}

Stem bleeding of coconut caused by Thielaviopsis paradoxa (de Seynes) Von Hohnel is an important disease affecting coconut in many countries (Menon and Pandalai, 1958; Ohler, 1966, Nambiar and Sastry, 1988). lsolation of the pathogen from diseased tissues on different agar based media has given inconsistent results (Anon., 1976; Anon., 1986), None of the selective media reported for certain related fungi viz., T. basicola (Berk and Br.) Ferr. (David, 1978; Tsao and Bricker, 1966) and Ceratocystis wagnerii Goheen and Cobb (Hicks et al., 1980) proved useful for the isolation of $T$. paradoxa Since, standardization of an isolation method is a basic necessity for any study on plant pathogens, an attempt was made to improve upon existing methods.

\section{MATERIALS AND METHODS}

Samples were collected from. 25 diseased palms near CPCR1, Kasaragod. Small pieces $(0.25$ x $0.25 \mathrm{~cm}$ ), cut from margin of infected stem tissues were sterilized with $0.1 \% \mathrm{HgC1}$ for 30 secs and washed thoroughly with sterile water. Two media viz. potato dextrose agar (PDA) and sugarcane juice agar (SJA; $200 \mathrm{ml}$ sugarcanc juice, $20 \mathrm{~g}$ agar powder and $800 \mathrm{ml}$ distilled water; $\mathrm{pH}$ 4.5), with and without addition of antimicrobial agents were compared with a bait method for the isolation of $T$. paradoxa Certain antimicrobial agents viz., sodium-diethyldithiocarbamate (100 ppm), sodium propionate $(1,000 \mathrm{ppm})$, oxbile $(1,000 \mathrm{ppm})$, streptomycin $(100 \mathrm{ppm})$, tetracycline $(50 \mathrm{ppm})$ and penicillin $(100 \mathrm{ppm})$ were added to media after screening a number of chemicals for their efficacy (Table 1). Infected bits were kept on agar surface of plates containing different media. Frond pieces (10-12 cm in length) frorn old coconut leaves were found most effective as bait (Table 2) and were used in subsequent studies. The pieces were inoculated with infected bits by bore-hole method (Nambiar et al., 1985), incubated at 30'C in polythene bags and isolations were made after 10 days of incubation from margin of rotten frond tissues on SJA. Response of $T$. parado to different media and baiting method was recorded.

\section{RESULTS AND DISCUSSION}

The data on successful isolation of T. paradoxa by different methods are presented in Table 3. The pathogen was isolated from $98.3 \%$ infected bits by bait method in comparison to $8.0-19.6 \%$ isolation on various media tested. SJA proved slightly better medium over PDA for the purpose. Addition of selected antimicrobial agents to the media did not favour the selective isolation of $T$. paradoxa_Colonies of many fungi viz., Aspergillu sp., Trichoderma sp., Pestalotia sp., Phoma sp. etc. were noticed in isolation plates of all agar-based media. Such contamination problem could be avoided by using bait-method. The failure of selective media, reported for isolation of related fungi, for obtaining isolation of $T$. paradox can be explained on the basis of observations presented in Table 1. Cycloheximide, Brassicol (pentachloro-nitrobenzene) and mycostatin at $100 \mathrm{ppm}$ and Rose Bengal at

$50 \mathrm{ppm}$ inhibited chlarnydospore germination or mycelial growth of $\mathrm{T}$. paradox or both to appreciable levels. These chernicals have been used in the selective media for T. basicola (David, 1978, Tsao, and Bricker, 1966) and C. wagnerii (Hicks 1980) at much higher contrations.

\footnotetext{
${ }^{1}$ Scientists, N.R.C.A.F., Pahug Dam, Jhansi (UP) India and Central Plantation Crops Research Institute, Kasaragod, India, respectively.
} 
Table l. Effect of some antifungal compounds, antibiotics and organic dyes on chlamydospore germination and mycelial growth of $T$. paradoxa

\begin{tabular}{|c|c|c|c|c|c|c|}
\hline \multirow{3}{*}{ Chemicals } & \multicolumn{6}{|c|}{ Chlamydospore germination/ mycelial growth at } \\
\hline & \multicolumn{2}{|c|}{$10 \mathrm{ppm}$} & \multicolumn{2}{|c|}{$50 \mathrm{ppm}$} & \multicolumn{2}{|c|}{$100 \mathrm{ppm}$} \\
\hline & Germination & Growth* & Germination & Growth & Germination & Growth \\
\hline Antifungal compouds & & & & & & \\
\hline Bavistin $50 \mathrm{WP}$ & 87.00 & 0.00 & 86.4 & 0.0 & 81.8 & 0.0 \\
\hline Brassicol $75 \mathrm{WP}$ & 15.2 & 52.5 & 17.6 & 45.0 & 8.9 & 40.0 \\
\hline Captaf 75 WP & 98.6 & 0.0 & 94.1 & 0.0 & 91.5 & 0.0 \\
\hline Copper sulphate & 100.0 & 100.0 & 63.5 & 91.3 & 55.0 & 57.5 \\
\hline Dithane M-45 (75\%) & 17.8 & 65.2 & 0.0 & 55.1 & 0.0 & 50.6 \\
\hline Foltaf $80 \mathrm{WP}$ & 0.0 & 35.0 & 0.0 & 28.8 & 0.0 & 27.5 \\
\hline Murcuric chloride & 17.4 & 73.0 & 0.0 & 37.1 & 0.0 & 8.9 \\
\hline Ox-bile & 99.1 & 100.0 & 86.7 & 100.0 & 87.6 & 97.2 \\
\hline $\begin{array}{l}\text { Sodium-diethyl-dith- } \\
\text { iocarbamate (Technical) }\end{array}$ & 100.0 & 69.6 & 100.0 & 67.4 & 79.6 & 65.1 \\
\hline Sodium propionate & 98.7 & 98.6 & 92.3 & 97.3 & 94.5 & 89.6 \\
\hline Vitavax $75 \mathrm{WP}$ & 23.6 & 73.7 & 0.0 & 30.0 & 0.0 & 16.3 \\
\hline Antibiotics & & & & & & \\
\hline Aureofungin Sol (30\%) & 33.4 & 56.3 & 0.0 & 0.0 & 0.0 & 0.0 \\
\hline Cycloheximide & 0.0 & 37.5 & 0.0 & 16.8 & 0.0 & 6.8 \\
\hline $\begin{array}{l}\text { Mycostatin }(4,960- \\
\text { units/mg) }\end{array}$ & 16.8 & 34.8 & 0.0 & 16.8 & 0.0 & 6.8 \\
\hline $\begin{array}{l}\text { Penicillin G (sodium- } \\
\text { salt > } 1435 \text { units/mg) }\end{array}$ & 100.0 & 96.3 & 99.5 & 92.5 & 96.4 & 80.0 \\
\hline $\begin{array}{l}\text { Pimaricin ( } 2.5 \text { aqueous- } \\
\text { susp.) }\end{array}$ & 51.2 & 31.4 & 29.7 & 30.0 & 0.0 & 26.6 \\
\hline Streptomycin sulphate & 97.1 & 97.2 & 98.2 & 97.2 & 100.0 & 97.2 \\
\hline $\begin{array}{l}\text { Tetracycline- } \\
\text { hydrochloride }\end{array}$ & 90.4 & 100.0 & 87.5 & 100.0 & 92.7 & 100.0 \\
\hline $\begin{array}{l}\text { Vancomycin } \\
\text { Organic dyes }\end{array}$ & 90.1 & 75.0 & 81.3 & 76.6 & 79.6 & 72.4 \\
\hline Rose bengal & 99.3 & 25.8 & 0.0 & 24.7 & 0.0 & 24.5 \\
\hline Melachite green & 0.0 & 21.3 & 0.0 & 17.5 & 0.0 & 17.5 \\
\hline
\end{tabular}

*Expressed as percentage of growth recorded on control medium @ Average of three replications 
Table 2: Effect of age on extent of coconut leaf frond fissue colonization after artificial inoculation with $T$. paradox

\begin{tabular}{|l|c|c|c|c|}
\hline \multirow{2}{*}{ Leaf position } & \multicolumn{4}{|c|}{ Extent of colonization* after } \\
\cline { 2 - 5 } & 4 days & 8 days & 12 days & 16 days \\
\hline 2 (upper whorl) & - & + & +++ & ++++ \\
12 (middle whort) & - & - & + & ++ \\
26 (lower whorl) & + & +++ & ++++ & ++++ \\
\hline
\end{tabular}

$*_{-}$: No decay; + : Decay up to $25 \% ;++$ : Decay from 26 to $50 \% ;+++$ : Decay from 51 to $75 \%$; ++++ : Decay $75 \%$

Table 3: Details of isolation of $T$. paradox from stem bleeding affected coconut palms by using different media/ method

\begin{tabular}{|l|c|c|}
\hline \multicolumn{1}{|c|}{ Media/method } & $\begin{array}{c}\text { No of bits from which } T . \\
\text { paradoxa was isolated }\end{array}$ & $\begin{array}{c}\text { No. of palms from which } T . \\
\text { paradox was isolated }\end{array}$ \\
\hline PDA & $21^{*}(8.4) \#$ & $11(44)$ \\
Amencled PDA & $20(8.0)$ & $13(52)$ \\
SJA & $49(19.6)$ & $22(88)$ \\
Amencled SJA & $28(10.8)$ & $17(68)$ \\
Host bait method & $248(99.2)$ & $25(100)$ \\
\hline
\end{tabular}

* 250 bits from 25 diseased palms ( 10 bits/palm) were used for isolation.

\# Figure in the parenthesis inclicate the percent isolation.

\section{CONCLUSIONS}

1. The results clearly bring out the advantage of using bait method for isolation of $T$. paradoxa from stern bleeding affected palms.

2. The method is highly reproduciable and by using it, continous association of T. paradox with the diseased palms could be established (Table 3). In past, the inconsistent isolations had created a lot of confusion regarding etiology of the disease (Anon., 1976; Anon., 1986). Thus, this confirms the finding of Nambiar et al. (1985), who successfully reproduced the disease symptoms by inoculating healthy trees with $T$. paradoxa

\section{ACKNOWLEDGEMENTS}

The authors are thankful to Dr. M.K. Nair, the Director. CPCRI, Kasaragod for providing encouragement and facilities. 


\section{REFERENCES}

1. ANON, 1976. Stern bleeding disease of coconut. CPCRI Annual Report CPCRI, Kasaragod, p. 62.

2. ANON, 1986. Stern bleeding disease of coconut. CPCRI Annual Report CPCRI, Kasaragod, p. 19.

3. DAVID, C.H. HSI. 1978. Effect of crop sequence, previous peanut blackhull severity, and time of sampling on soil population of Thielaviopsis basicola. Phypatholog 68: 1442-1445.

4. HICKS, B.R., COBB, F.W.R., AND GERSPER. P.L. 1980. Isolation of Ceratocystis wagener from forest soil with a selective m.edium. Phytopathology 70: 880-883.

5. MENON, K.P.V., and PANDALAI, K.M. 1960. The coconut palm A monograph. Published by Indian Central Coconut Committee p. 384.

6. NAMBIAR, K.K.N., JOSHI, Y., VENUGOPAL, M.N., and MOHAN, R.C. 1985. Stem bleeding disease of coconut: Reproduction of symptorns by inoculation with Thielaviopsis paradoxa. J. Plantation Crop 14: 130-133.

7. NAMBIAR, K.K.N., and SASTRY, R.K. 1988. Stern bleeding disease of coconut: Current status and approaches for its control. Philippine J. Coconut Studies 13(1) : 30-32.

8. OHLER, J.G. 1964. Coconut-Tree of Life. Published by FAO. Rome. p. 446.

9. TSAO, P.H., and BRICKER, J.L. 1966. Chlamyclospores of Thielaviopsis basicola as surviving propagules in natural soils. Phytopathology 56(9): 1012-1014. 